\title{
Intentions to Pursue a Career in Information Systems and Technology: An Empirical Study of South African Students
}

\author{
Jason F. Cohen and Poonam Parsotam
}

School of Economic and Business Sciences, University of the Witwatersrand, 2050 Johannesburg, South Africa

jason.cohen@wits.ac.za

\begin{abstract}
This paper reports on a study of the IT career interests of 263 South African university students. Drawing primarily on social cognitive career theory, a number of variables were selected and their effects on student intentions to pursue an IT career and choice of major were examined. Results revealed very low IT career intentions amongst students. Occupational self-efficacy, computing experience, computer anxiety, computer self-efficacy, and perceived career rewards were found to be important factors. Student perceptions of the core introductory IS course are also strongly linked to their intentions. Demography (gender and race) had mostly indirect effects.
\end{abstract}

Keywords: Careers, choice of major, self-efficacy, computer anxiety, computer attitude, experience, outcome expectations.

\section{Introduction}

A strong information technology (IT) workforce is considered part of the core human capital needs of a knowledge society. However, high school and university students are expressing little interest in pursuing information systems (IS) or IT careers, and enrolment figures in IT related majors has declined globally since the Dot-com failures of 2001 [1], [2]. Although there are some reports that enrolments may soon increase, there remains concern over impending IT workforce and skills shortages [3]. To better predict enrolment trends, IT educators are calling for an improved understanding of factors associated with students' IT career intentions and choice of major.

Initial contributions describe changing enrollment patterns and the outlook for IT graduate demand e.g. [4], and point to external market factors, including the general economy and the outsourcing phenomenon, as driving students away from IT [5]. Some researchers have chosen to direct attention inward at IS/IT faculty. They recommend changes to course design and the use of leading edge technology as ways to attract and retain students [6], [7], [8].

Yet, others consider student backgrounds, attitudes and their perceptions of IT as the primary determinants of their career and study choices. To this end, some exploratory studies are uncovering student awareness and expectations of an IT career [9], the factors important to them in the selection of a major [10], [11], as well as the 
stereotypes they may have of IS/IT professionals [2]. The role of gender and ethnicity in influencing attitudes and IT career intentions has also been explored [12] along with perceptions of job availability, interests in IS, perceptions of the curriculum, and views of family and professors [13]. Recently, social cognitive career theory has been drawn upon to successfully test a model of students' intentions to select a computing major. This theory models student intentions as a function of their interests, selfefficacy beliefs and outcome expectations [14].

The aim of this study is to contribute to such explanations of student interest in IT oriented careers. We draw on social cognitive career theory (SCCT), and prior work in the IT career literature, to examine a set of factors for their influence on South African students' interests and intentions in relation to IT careers.

The success of the knowledge society will require a committed and dedicated IS/IT workforce and being able to influence, impact and predict the career choices of our students is important to preventing potential labor shortages [10]. Therefore, by identifying the factors that influence student intentions, we can prevent missed opportunities for attracting students into the field, we can define interventions to address those factors within our full or partial control, and we can understand the nature and extent of the impact of those factors outside of our immediate control.

\section{Background to the Study}

This study focuses on both 'choice of major' and 'career intention' as reflections of student interest in IT. This allows us to make a distinction between the educational aspirations of students and their career aspirations. IT career intention is a career aspiration and is defined as the subjective probability of the student choosing to pursue a career in the IT field [12]. Choice of major, on the other hand, is considered an educational aspiration and thus part of the preparation for a career choice [15] but not a precise determinant [16], [17]. Although a number of degree programs exist to serve the educational aspirations of students interested in IT [18], we focused on the study of Commerce students and their intentions to major in Information Systems.

\subsection{Research Variables}

SCCT describes the career development process by explaining through Bandura's social cognitive theory how people will develop goals for future activity involvement, such as the intention to select a college major or to pursue a career path, consistent with their interests, self-efficacy assessments and positive outcome expectations [15]. For this reason, this study explores student self-efficacy beliefs, attitudes and interest in IT, and outcome expectations (rewards) of an IT career.

SCCT also accounts for perceived barriers to career development that might influence career choices [17]. Even if an individual possesses high levels of selfefficacy and interest, perceived barriers to career entry or advancement may still inhibit the translation of interests into career choice [19]. Perceived barriers may arise from differential opportunities for development (e.g. education), or perceptions of gender or ethnic discrimination in the associated career. For this reason, this study also explores students' differential experiences and backgrounds in computing as well as their demography in an effort to better understand their career intentions. 
Demography: There is concern that the under-representation of certain demographic groups in the IT field is limiting the human capital potential of the knowledge society [20]. Specifically, participation of females and certain ethnic/racial groups in the IT field has received attention and efforts to understand their perceptions and motivations to study and work in IT have been underway for the past decade e.g. [21]. Our study therefore seeks to provide additional empirical evidence on gender differences and the effects of racial demography on IT career intention and choice to major in IS.

Computer experience: Past research considers prior computer education (in high school), personal computer (PC) ownership, computer usage, and years since first contact with computers as key indicators of computing experience [22], [23]. Computer experience and past success may reduce career bias and inspire career choice [9], [24]. We therefore expect student computer experience to associate with IT career intention and the choice to major in IS.

Occupational self-efficacy is considered in SCCT to have a direct effect on career choice [16], and is defined as an individual's belief in their ability to succeed in a given career. Lent et al. [14] consider self-efficacy to influence choice of major directly and indirectly through effects on interest and outcome expectations. Johnson et al. [12] found that students' perceptions of their ability to work in the IT field correlated with attitude toward IT jobs, and Walstrom et al. [10] identify "I'm not suited for IT type work" amongst the reasons for students not wanting to pursue IT studies or an IT career. We thus expect student occupational self-efficacy to correlate with IT career intention and choice to major in IS.

Computer self-efficacy is an individual's confidence in their computer-related abilities. Research suggests that individuals who have high computer self-efficacy are more likely to be interested in IT studies [8]. We thus expect student computer selfefficacy beliefs to correlate with IT career intention and choice to major in IS.

Computer anxiety is the affective response of individuals when they use (or consider the possibility of using) computers and will manifest as worries, apprehensions, tensions and fear [25]. Computer anxious individuals are more reluctant to use computers [23], will generally avoid them [26], and may perform more poorly on computer-based tasks [27]. We consider that a student's computer anxiety may become a career and educational barrier, which will be inversely associated with IT career intention and choice to major in IS.

Attitude toward computers is an individual's feelings about the usefulness and impacts of computers for society and for their own daily lives [25], [28]. Negative attitudes and lack of interest are frequently cited reasons for why students do not select an IT major [9], [10]. We expect attitude toward computers and their usefulness to correlate with IT career intention and choice of major.

Perception of IT career rewards: SCCT suggests that individuals develop interest in activities which they believe will lead to positive outcomes - including anticipated tangible, social and self-evaluative outcomes [15]. Outcome expectations rank amongst the most important considerations in student selection of a major [9], [10], while perceptions of poor career prospects and lack of enjoyable work rank among the reasons cited for not selecting an IS major [29], [30]. We examine student perceptions of both tangible IT career outcomes (e.g. earning an attractive salary, job security) and perceptions of social and self-evaluative outcomes (e.g. doing satisfying work, doing good for society, and having a good home life), and expect them to influence IT career intention and choice of major. 
Through the introductory IS course, IS/IT Faculty can positively influence student attitude, increase perceptions of career rewards [8] and enhance IT interest [6], [7]. Given that the introductory IS course is a core degree requirement for all students participating in this study, we examine whether the introductory course is stimulating student interest in IT.

\section{Methods}

The study was conducted at the authors' institution - the University of the Witwatersrand, Johannesburg. The sampling frame consisted of 536 first year Bachelor of Commerce (BCom) students enrolled in a core introductory information systems course. Each of the students would subsequently have the option to abandon further IS studies or continue with the subject as a major. Students were invited to participate. Participation was completely voluntary and neither penalty nor benefit was attached to their participation ${ }^{2}$.

\subsection{Instrument}

The survey instrument was a structured questionnaire. It was made available to students during their class session and clearance was obtained from the University's ethics committee.

The questionnaire asked demographic questions about age, gender and race. The questionnaire also asked students about their computer experience including a) whether they had taken an IT subject in high-school, b) whether they owned a personal computer $(\mathrm{PC}), \mathrm{c})$ the number of years they had been using computers, and $\mathrm{d}$ ) the average amount of time spent on the computer per day ( $1=$ less than one hour to $4=$ more than 6 hours). Computer self-efficacy was measured using 10 items from Murphy et al. [31] on a 5-point scale. However, after principal components analysis (PCA), five items were removed as they seemed to capture more basic levels of self-efficacy, the remaining five items tapped into a more advanced computing selfefficacy factor and included items measuring student confidence in ability to troubleshoot computer problems, write simple programs, and understand issues related to hardware and software compatibility and the stages of data processing $(\alpha=0.75)$. General computer anxiety was measured using six items adapted from Nickell and Pinto [28] and Heinssen et al. [25] on a 5-point scale. Items asked about fear and intimidation in relation to computer usage in a work related context $(\alpha=0.87)$. Computer attitude was measured by asking students the extent to which they agreed with eight statements reflecting positive attitudes toward computers. The scale was adapted from Nickell and Pinto [28]. Following PCA, one item was eliminated and

${ }^{1}$ The University of the Witwatersrand, Johannesburg is divided into 5 Faculties comprising 34 Schools. It is a research focused university and, as one of only 5 universities in Africa (universities of Cape Town, Cairo, Natal and Pretoria being the other four) that are listed in the Shanghai Jaio Tong Top 500 rankings, it has an important role to play in Africa's hopes to become a knowledge society.

${ }^{2}$ Over the last decade, enrollments for further study in IS have fallen roughly $70 \%$ from their peak at the beginning of the millennium. The largest drop occurred in 2003 where enrollment fell by almost 50\%, and in 2004 enrollments toward the major fell below 100 for the first time. 
the remaining seven items captured student attitudes toward the impacts of computers on individuals, business and society $(\alpha=0.83)$. Perceived IT career rewards were captured through seven items [32] measured on a 5-point scale. Principal components analysis confirmed these items loaded onto two factors with five items reflecting perceived personal and social rewards $(\alpha=0.70)$ and two items reflecting perceived tangible rewards $(\alpha=0.66)$. Perceptions of the introductory IS course was measured using three items measured on a 5-point scale to assess the extent to which the various components of the course were stimulating the student's interest in IT $(\alpha=0.82)$. Occupational self-efficacy was measured using a single item asking students if they believed they possessed the skills and abilities needed to pursue an IT career. Intention to pursue a career in IT was measured using four items $(\alpha=0.93)$, which were adapted from Brinkley and Scholar [32]. These items captured student interest and intention to pursue an IT related career. Students were also asked to identify their most likely choice of major, and were provided an opportunity to select from across the options for a BCom major at the university e.g. Accounting, Finance, Economics, Human Resources, Information Systems, Management, and Marketing among others.

To facilitate subsequent analysis composite scores were created for the multi-item scales as the arithmetic average of the scale items weighted equally.

\section{Findings}

Roughly half the students $(n=263)$ consented to participate by completing the survey instrument. The proportion of females/males and race groups returning the questionnaire was quite consistent with the overall demographic of the registered students and the sample is considered representative.

Approximately $15 \%$ of students $(n=41)$ identified themselves as intending to major in IS. This is consistent with the proportion of IS/non-IS majors reported in a recent article [6] but also more promising than others [10]. Students who indicated their intentions were not to major in IS identified their most likely choice of major as Accounting/Finance $(n=110)$ or Business Sciences/Economics $(n=100)$, with very few undecided.

\subsection{Demography and Computer Experience}

Roughly $75 \%$ of the students report owning a personal computer (PC). Unfortunately, amongst South African students, PC ownership is not independent of race $\left(\chi^{2}=40.15\right.$, $\mathrm{p}<0.001)$. Black students account for $96 \%$ of the students reporting no computer ownership. There is also a statistically significant difference $\left(\chi^{2}=33.65, \mathrm{p}<0.01\right)$ between race groups in years of computer experience. While most White and Indian students have been using computers for more than 6 years, about $40 \%$ of Black students had less than 2 years experience.

About half the students use computers for 2-3 hours per day, only $10 \%$ report that they spend more than 4 hours per day on the computer. There was no statistically significant difference across race or gender in usage.

Table 1 examines student intention to major in IS and finds, using $\chi^{2}$ tests, that intention to major in IS is independent of age, race, gender, and all computer experience indicators except for past high school IT education. Students that take IT/computer 
studies in high school are more likely to major in IS at university level. It is pleasing to note that the taking of an IT subject in high school is independent of both race and gender, however only $20 \%$ of the students had taken an IT subject in high school and only $30.8 \%$ of those were intending to major in IS. This suggests that educational aspirations in high school do not necessarily translate into educational aspirations at university level and confirms students will "branch out" from high school experiences when considering career prospects [9].

Table 1. Comparison on Demographics and Computer Experience (Intention to Major)

\begin{tabular}{|c|c|c|c|c|}
\hline \multicolumn{2}{|c|}{$\begin{array}{l}\text { Student Demographics and Computing } \\
\text { Experience }\end{array}$} & $\begin{array}{l}\text { No Intention to } \\
\text { Major in IS } \\
(\mathrm{n}=222)\end{array}$ & $\begin{array}{l}\text { Intention to } \\
\text { Major in IS } \\
(\mathrm{n}=41)\end{array}$ & p-value \\
\hline \multirow[t]{2}{*}{ Age } & $<20$ & $199(84.3 \%)$ & $37(15.7 \%)$ & \multirow{2}{*}{0.910} \\
\hline & $>20$ & $21(84 \%)$ & $4(16 \%)$ & \\
\hline \multirow[t]{2}{*}{ Gender } & Male & $95(84.1 \%)$ & $18(15.9 \%)$ & \multirow{2}{*}{0.895} \\
\hline & Female & $127(84.7 \%)$ & $23(15.3 \%)$ & \\
\hline \multirow[t]{5}{*}{ Race } & Black & $142(84.5 \%)$ & $26(15.5 \%)$ & \multirow{5}{*}{0.108} \\
\hline & White & $34(82.9 \%)$ & $7(17.1 \%)$ & \\
\hline & Indian & $38(92.7 \%)$ & $3(7.3 \%)$ & \\
\hline & Asian & $4(57.1 \%)$ & $3(42.9 \%)$ & \\
\hline & Other & $4(66.7 \%)$ & $2(33.3 \%)$ & \\
\hline \multirow[t]{2}{*}{ IT subject taken in high school } & Yes & $36(69.2 \%)$ & $16(30.8 \%)$ & \multirow{2}{*}{0.001} \\
\hline & No & $185(88.1 \%)$ & $25(11.9 \%)$ & \\
\hline \multirow[t]{2}{*}{ PC ownership } & Yes & $165(85.5 \%)$ & $28(14.5 \%)$ & \multirow{2}{*}{0.344} \\
\hline & No & $54(80.6 \%)$ & $13(19.4 \%)$ & \\
\hline \multirow[t]{4}{*}{ Hours of computer use (p/day) } & $0-1$ hours & $85(87.6 \%)$ & $12(12.4 \%)$ & \multirow{4}{*}{0.729} \\
\hline & $2-3$ hours & $115(82.7 \%)$ & $24(17.3 \%)$ & \\
\hline & 4-5 hours & $15(78.9 \%)$ & $4(21.1 \%)$ & \\
\hline & $>6$ hours & $5(100 \%)$ & $0(0 \%)$ & \\
\hline \multirow{5}{*}{ Years of computer use } & $<1$ year & $44(83 \%)$ & $9(17 \%)$ & \multirow{5}{*}{0.746} \\
\hline & $1-2$ years & $24(85.7 \%)$ & $4(14.3 \%)$ & \\
\hline & $2-4$ years & $33(91.7 \%)$ & $3(8.3 \%)$ & \\
\hline & 4-6 years & $26(81.3 \%)$ & $6(18.7 \%)$ & \\
\hline & $>6$ years & $93(83 \%)$ & $19(17 \%)$ & \\
\hline
\end{tabular}

* sum of numbers differs from total $\mathrm{n}$ due to missing data in some cases.

Table 2 reveals that intentions to pursue an IT career are generally very low, and in all cases below the scale mid-point of 3 except for those intending to major in IS. Those students that took IT courses in high school are also significantly more interested in pursuing an IT related career. These findings confirm a significant relationship between career intention and educational aspiration.

Hours of computer use per day is also associated with intention, with Tukey posthoc analysis confirming a significant difference between the group of students using computers for less than 1 hour per day and the group using computers for between 2 to 3 hours. Similar to Seymour et al. [33], it is interesting to note slightly higher interest amongst students that do not own computers.

While SCCT suggests that perceived gender or ethnic discrimination could act as a barrier to career choice, neither gender nor race were directly related to career choice. 
Table 2. Comparison on Demographics and Computer Experience (Intention to Pursue IT Career)

\begin{tabular}{|c|c|c|c|}
\hline $\begin{array}{l}\text { Student Demographics and } \\
\text { Experience }\end{array}$ & Computing & $\begin{array}{l}\text { Mean Career } \\
\text { Intention } \\
\text { Score } \pm \text { SD. }\end{array}$ & $\begin{array}{l}t \text {-value (sig.) / } \\
\text { F-value (sig.) }\end{array}$ \\
\hline Age & $\begin{array}{l}<20 \\
>20\end{array}$ & $\begin{array}{l}2.40 \pm 1.1 \\
2.39 \pm 1.2\end{array}$ & $t=0.027(\mathrm{p}=0.979)$ \\
\hline Gender & $\begin{array}{l}\text { Male } \\
\text { Female }\end{array}$ & $\begin{array}{l}2.49 \pm 1.1 \\
2.32 \pm 1.1\end{array}$ & $t=1.184(\mathrm{p}=0.238)$ \\
\hline Race & $\begin{array}{l}\text { Black } \\
\text { White } \\
\text { Indian } \\
\text { Asian } \\
\text { Other }\end{array}$ & $\begin{array}{l}2.42 \pm 1.2 \\
2.26 \pm 1.1 \\
2.40 \pm 1.1 \\
2.60 \pm 0.9 \\
2.55 \pm 1.5\end{array}$ & $\mathrm{~F}=0.237(\mathrm{p}=0.917)$ \\
\hline IT subject taken in high school & $\begin{array}{l}\text { Yes } \\
\text { No }\end{array}$ & $\begin{array}{l}2.75 \pm 1.3 \\
2.31 \pm 1.1\end{array}$ & $t=2.522(\mathrm{p}=0.012)$ \\
\hline PC ownership & $\begin{array}{l}\text { Yes } \\
\text { No }\end{array}$ & $\begin{array}{l}2.36 \pm 1.1 \\
2.51 \pm 1.9\end{array}$ & $t=-0.924(\mathrm{p}=0.356)$ \\
\hline Hours of computer use (p/day) & $\begin{array}{l}0-1 \text { hours } \\
2-3 \text { hours } \\
4-5 \text { hours } \\
>6 \text { hours }\end{array}$ & $\begin{array}{l}2.12 \pm 1.0 \\
2.56 \pm 1.2 \\
2.68 \pm 1.3 \\
2.10 \pm 1.1\end{array}$ & $\mathrm{~F}=3.473(\mathrm{p}=0.017)$ \\
\hline Years of computer use & $\begin{array}{l}<1 \text { year } \\
1-2 \text { years } \\
2-4 \text { years } \\
4-6 \text { years } \\
>6 \text { years }\end{array}$ & $\begin{array}{l}2.60 \pm 1.2 \\
2.13 \pm 0.9 \\
2.43 \pm 1.1 \\
2.59 \pm 1.3 \\
2.30 \pm 1.2\end{array}$ & $\mathrm{~F}=1.219(\mathrm{p}=0.303)$ \\
\hline Intention to major in IS & $\begin{array}{l}\text { Yes } \\
\text { No }\end{array}$ & $\begin{array}{l}4.08 \pm 0.7 \\
2.08 \pm 0.9\end{array}$ & $t=13.188(\mathrm{p}<0.001)$ \\
\hline
\end{tabular}

\subsection{Self Efficacy, Anxiety, Attitudes and Perceptions}

Table 3 shows that the male students have higher levels of computer self-efficacy $(t=$ $3.5, \mathrm{p}<0.001)$ and lower levels of computer anxiety $(t=2.6, \mathrm{p}<0.05)$ than their female counterparts. This is consistent with prior literature [12], [26]. Race also tends to be associated with computer anxiety, with Black and Indian students demonstrating the highest anxiety levels $(\mathrm{F}=2.54, \mathrm{p}<0.05)$. Prior education in computing appears important to increasing self-efficacy $(t=5.83, \mathrm{p}<0.001)$ and reducing anxiety $(\mathrm{t}=5.0$, $\mathrm{p}<0.001)$. We also found PC ownership reduces anxiety $(t=2.1, \mathrm{p}<0.05)$, that students using computers between 4-5 hours per day have the highest self-efficacy levels $(\mathrm{F}=5.26, \mathrm{p}<0.01)$, and that students with fewer years of experience have the highest anxiety levels $(\mathrm{F}=10.77, \mathrm{p}<0.001)$. This confirms prior analyses in other contexts and suggests that computer anxiety is a 'state anxiety' that can be manipulated by training and exposure [23], [26], [34].

We find students with higher computer self-efficacy $(t=5.1, \mathrm{p}<0.001)$ and lower anxiety $(t=4.7, \mathrm{p}<0.001)$ are more likely to major in IS. All students seemed to share a positive attitude towards computers independent of gender, race, computing experience or choice of major. This supports the view that students not majoring in IS do not necessarily have negative perceptions of the field [2], but frequent users do have the highest positive attitudes toward computers $(\mathrm{F}=4.07, \mathrm{p}<0.01)$. 
An independent sample t-test $(t=3.08, \mathrm{p}<0.01)$ confirms that females have lower IT occupational self-efficacy than males. We did not find differences by race. Occupational self-efficacy is highest for PC owners $(t=2.14, \mathrm{p}<0.05)$, those who took IT in high school $(t=5.23, \mathrm{p}<0.001)$, those intending to major in IS $(t=6.22, \mathrm{p}<0.001)$, those who've been using computers for longer $(\mathrm{F}=2.710, \mathrm{p}<0.05)$ and are more frequent users $(\mathrm{F}=6.270, \mathrm{p}<0.001)$.

Table 4 presents results of correlation analyses between student intention to pursue an IT career and the various computing attitudes and career perceptions. All variables are significantly associated with career intention except computer attitude.

We also confirm that students intending to major in IS differ significantly from those with no intentions on the perceived tangible rewards of an IT career $(t=3.78$, $\mathrm{p}<0.001)$ and the perceived personal and social rewards of an IT career $(t=7.26$, $\mathrm{p}<0.001)$. The mean \pm SD for perceived tangible rewards of total sample, intended IS majors and non-IS majors was $3.38 \pm 0.82 ; 3.82 \pm 0.70$; and $3.30 \pm 0.81$ respectively. The mean \pm SD for perceived personal and social rewards for the total sample, intended IS majors and non-IS majors was 3.24 $0.69 ; 3.89 \pm 0.54$; and $3.11 \pm 0.64$ respectively. Thus changing student perceptions of IT careers is an important intervention needed to secure increased enrolment.

Table 3. Student Self Efficacy, Anxiety and Attitude

\begin{tabular}{|c|c|c|c|c|c|}
\hline \multicolumn{2}{|c|}{$\begin{array}{l}\text { Student Demographics and } \\
\text { Computing Experience }\end{array}$} & $\begin{array}{l}\text { Occupa- } \\
\text { tional } \\
\text { Self } \\
\text { Efficacy }\end{array}$ & $\begin{array}{l}\text { Computer } \\
\text { Self } \\
\text { Efficacy }\end{array}$ & $\begin{array}{l}\text { Computer } \\
\text { Attitude }\end{array}$ & $\begin{array}{l}\text { Computer } \\
\text { Anxiety }\end{array}$ \\
\hline \multirow[t]{2}{*}{ Age } & $<20$ & 2.92 & 3.17 & 4.21 & 1.97 \\
\hline & $>20$ & 2.60 & 3.27 & 4.29 & 1.99 \\
\hline \multirow[t]{2}{*}{ Gender } & Male & $3.13 * *$ & $3.36 * * *$ & 4.18 & $1.82 * *$ \\
\hline & Female & 2.69 & 3.04 & 4.25 & 2.10 \\
\hline \multirow[t]{5}{*}{ Race } & Black & 2.85 & 3.26 & 4.23 & $2.02 *$ \\
\hline & White & 3.07 & 3.20 & 4.22 & 1.70 \\
\hline & Indian & 2.85 & 2.90 & 4.17 & 2.22 \\
\hline & Asian & 3.00 & 2.97 & 4.14 & 1.62 \\
\hline & Other & 2.65 & 3.06 & 4.30 & 1.58 \\
\hline \multirow{4}{*}{$\begin{array}{l}\text { IT subject taken in high } \\
\text { school } \\
\text { PC ownership }\end{array}$} & Yes & $3.60 * * *$ & $3.68 * * *$ & 4.26 & $1.54 * * *$ \\
\hline & No & 2.70 & 3.05 & 4.20 & 2.09 \\
\hline & Yes & $2.98^{*}$ & 3.19 & 4.22 & $1.90 *$ \\
\hline & No & 2.63 & 3.18 & 4.22 & 2.17 \\
\hline \multirow{4}{*}{$\begin{array}{l}\text { Hours of computer use } \\
\text { (p/day) }\end{array}$} & 0-1 hours & $2.53 * *$ & 2.97 & 4.10 & 2.03 \\
\hline & 2-3 hours & 3.05 & 3.29 & 4.24 & 2.00 \\
\hline & 4-5 hours & 3.53 & $3.50 * *$ & $4.59 * *$ & 1.78 \\
\hline & $>6$ hours & 2.80 & 3.04 & 4.26 & 1.87 \\
\hline \multirow{5}{*}{ Years of computer use } & $<1$ year & 2.59 & 3.06 & 4.29 & $2.52 * * *$ \\
\hline & $1-2$ years & 2.57 & 2.99 & 4.10 & 2.16 \\
\hline & 2-4 years & 2.78 & 3.20 & 4.18 & 2.11 \\
\hline & 4-6 years & $3.22 *$ & 3.24 & 4.27 & 1.98 \\
\hline & $>6$ years & 3.04 & 3.26 & 4.20 & 1.65 \\
\hline \multirow[t]{2}{*}{ Intention to major in IS } & Yes & $3.85 * * *$ & $3.69 * * *$ & 4.28 & $1.61 * * *$ \\
\hline & No & 2.70 & 3.08 & 4.20 & 2.05 \\
\hline
\end{tabular}

$* \mathrm{p}<0.05 * * \mathrm{p}<0.01 * * * \mathrm{p}<0.001$. 
Table 4. Correlates of Student IT Career Intention

\begin{tabular}{ll}
\hline & IT Career Intention \\
\hline Computer Self-Efficacy & $0.386^{* * *}$ \\
Computer Anxiety & $-0.141^{*}$ \\
Computer Attitude & 0.082 \\
Perception of Introductory Course & $0.549^{* * *}$ \\
Perception of Tangible Career Rewards & $0.266^{* * *}$ \\
Perception of Personal/Social Career Rewards & $0.608^{* * *}$ \\
Occupational Self-Efficacy & $0.805^{* * *}$ \\
\hline
\end{tabular}

$* \mathrm{p}<0.05 * * \mathrm{p}<0.01 \quad * * * \mathrm{p}<0.001$

In evaluating perceptions of the introductory IS course, we found a statistically significant difference $(t=5.29, \mathrm{p}<0.001)$ between those students intending to major in IS $(3.85 \pm 0.86)$ and those reporting no interest $(2.95 \pm 1.02)$. However, it was sobering to observe that interest in IT was not being peaked very high for either group of students (less than 4 on the 5-point measurement scale).

Logistic regression indicated that set of variables (from Table 4) was 96\% accurate in predicting the decision of students not to major in IS, but only $39 \%$ accurate in predicting the decision of students to major in IS. This suggests that while we are able to explain what leads to lack of interest, we are not as successful in predicting which students will be drawn to the IS major.

\section{Conclusion}

Declining student numbers in IT related disciplines is a cause for concern and a problem that has implications for the human capital potential of the knowledge society. We therefore sought to uncover the factors associated with students' intentions to major in Information Systems and pursue an IT career.

Results based on an analysis of 263 first year students unfortunately reveals very low IT career intentions amongst students, and only $15 \%$ of students indicated an intention to major in IS. This study has contributed to our understanding of these intentions by showing that the determinants of career choice, as predicted by social cognitive career theory, have deep psychological roots. We found that career and study choices reflect perceptions and expectations of reward (outcomes) and are driven by interests, anxieties, and self-efficacy beliefs. Importantly, we have also found that career aspirations tend to start much earlier than University level. Years of computing experience, early computer education, and PC ownership appear to have direct and indirect impacts on study and career choices.

Demography (gender and race) was also found to exert indirect effects on IT career intention and choice of major. Improving both occupational and computer selfefficacy and reducing computer anxiety amongst females may be critical to increasing their interest in an IT career. We also find that increasing the computer experience amongst Black students and reducing their anxiety may be important factors in raising their IT career interests.

Future research may wish to extend our examination to include variables such as subjective-norm and perceptions of job availability and the skills gap. Future research 
may want to account for the misperceptions that students may have of IT careers, for example that there are only technical career options. Repeat measures studies should be designed to explore how student attitudes, anxieties, self-efficacy, career perceptions and intentions to major change over the duration of the introductory course as certain interventions are made to curriculum design and course structure.

\section{References}

1. Becker, J., Hassan, N., Naumann, J.D.: Combating the Enrollment Downturn in IS/IT Programs. In: Proceedings of the Twelfth AMCIS, Acapulco, Mexico (2006)

2. Akbulut-Bailey, A.Y.: A Measurement Instrument for Understanding Student Perspectives on Stereotypes of IS Professionals. Commun. AIS 25, 321-338 (2009)

3. Beise, C.M., Robbins, J., Kaiser, K., Niederman, F.P.: The Information Systems Enrollment Crisis: Status and Strategies. In: SIGMS-CPR, Limerick, pp. 215-216 (2009)

4. George, J.F., Valacich, J.S., Valor, J.: Does Information Systems Still Matter? Lessons for a Maturing Discipline. In: Proceedings ICIS, Washington, pp. 1039-1048 (2004)

5. Baskerville, R., Adam, A., Krcmar, H., Peppard, J., Venable, J.: Panel: IT Employment and Shifting Enrolment Patterns in Information Systems. In: Proceedings of the Thirteenth ECIS, Regensburg, Germany, pp. 26-28 (2005)

6. Firth, D., Lawrence, C., Looney, C.A.: Addressing the IS Enrollment Crisis: a 12-step Program to Bring about Change through the Introductory IS Course. Commun. AIS 23, 17-36 (2008)

7. Street, C., Wade, M.: Reversing the Downward Trend: Innovative Approaches to IS/IT Course Development and Delivery. In: Proceedings ICIS, Montreal, pp. 1-5 (2007)

8. Akbulut, A.Y., Looney, C.A.: Improving IS Student Enrollments: Understanding the Effects of IT Sophistication in Introductory IS Courses. J. Information Technology Education 8, 87-100 (2009)

9. McInerney, C.R., DiDonato, N.C., Giagnacova, R., O’Donnell, A.M.: Students' Choice of Information Technology Majors and Careers: a Qualitative Study. Information Technology, Learning, and Performance Journal 24(2), 35-53 (2006)

10. Walstrom, K.A., Jones, K.T., Crampton, W.J.: Why are Students Not Majoring in Information Systems? J. Information Systems Education 19(1), 43-52 (2008)

11. Ferratt, T.W., Hall, S.R., Prasad, J., Wynn, D.E.: Why Students Choose MIS: What Makes a Major-Job-Career in Management Information Systems Interesting? In: ACM SIGMISCPR, Limerick, pp. 57-61 (2009)

12. Johnson, R.D., Stone, D.L., Phillips, T.N.: Relations Among Ethnicity, Gender, Beliefs, Attitudes, and Intention to Pursue a Career in Information Technology. J. Appl. Soc. Psychol. 38(4), 999-1022 (2008)

13. Zhang, W.: Why IS: Understanding Undergraduate Students' Intentions to Choose an Information Systems Major. J. Information Systems Education 18(4), 447-458 (2007)

14. Lent, R.W., Lopez, A.M., Lopez, F.G., Sheu, H.: Social Cognitive Career Theory and the Prediction of Interests and Choice in the Computing Disciplines. J. Vocat. Behav. 73, 52-62 (2008)

15. Lent, R.W., Brown, S.D., Hackett, G.: Toward a Unifying Social Cognitive Theory of Career and Academic Interest, Choice, and Performance. J. Vocat. Behav. 45, 79-122 (1994)

16. Rottinghaus, P.J., Lindley, L.D., Green, M.A., Borgen, F.H.: Educational Aspirations: The Contribution of Personality, Self-efficacy, and Interest. J. Vocat. Behav. 61, 1-19 (2002) 
17. Lindley, L.D.: Perceived Barriers to Career Development in the Context of Social Cognitive Career Theory. J. Career Assessment 13(3), 271-287 (2005)

18. Computing Curricula 2005, Report of the Joint ACM and IEEE Curriculum Taskforce (2005), http: / /www.acm.org/education/curric_vols/CC2005March06Final.pdf

19. Albert, K.A., Luzzo, D.A.: The Role of Perceived Barriers in Career Development: a Social Cognitive Perspective. J. Couns. Dev. 77(4), 431-436 (1999)

20. Trauth, E.M., Quesenberry, J.L., Huang, H.: A Multicultural Analysis of Factors Influecing Career Choice for Women in the Information Technology Workforce. J. Global Information Management 16(4), 1-23 (2008)

21. Nielsen, S.H., von Hellers, L.A., Greenhill, A., Pringle, R.: Conceptualising the Influence of Cultural and Gender Factors on Students' Perceptions of IT Studies and Careers. In: ACM SIGCPR Conference on Computer Personnel Research, Boston (1998)

22. Korobili, S., Togia, A., Malliari, A.: Computer Anxiety and Attitudes Among Undergraduate Students in Greece. Comput. Hum. Behav. (in Press), http://dx.doi.org/ $10.1016 / j$.chb.2009.11.011

23. Bozionelos, N.: Socio-Economic Background and Computer Use: the Role of Computer Anxiety and Computer Experience in Their Relationship. Int. J. Hum-Comput. St. 61, 725-746 (2004)

24. Adya, M., Kaiser, K.M.: Early Determinants of Women in the IT Workforce: a Model of Girls' Career Choices. Inform. Technol. and People 18(3), 230-259 (2005)

25. Heinssen, R.K., Glass, C.R., Knight, L.A.: Assessing Computer Anxiety: Development and Validation of the Computer Anxiety Rating Scale. Comput. Hum. Behav. 3(1), 49-59 (1987)

26. Chua, S.L., Chen, D., Wong, A.F.L.: Computer Anxiety and its Correlates: a MetaAnalysis. Comput. Hum. Behav. 15, 609-623 (1999)

27. Mahar, D., Henderson, R., Deane, F.: The Effects of Computer Anxiety, State Anxiety, and Computer Experience on Users' Performance of Computer Based Tasks. Pers. Indiv. Differ. 22(5), 683-692 (1997)

28. Nickell, G.S., Pinto, J.N.: The Computer Attitude Scale. Comput. Hum. Behav. 2(4), $301-$ 306 (1986)

29. Lomerson, W.L., Pollacia, L.: CIS Enrollment Decline: Examining Pre-College Factors. In: Proceedings Southern AIS Conference, Jacksonville, pp. 93-103 (2006)

30. Granger, M.J., Dick, G., Jacobson, C.M., Van Slyke, C.: Information Systems Enrollments: Challenges and Strategies. J. Information Systems Education 18(3), 303-311 (2007)

31. Murphy, C.A., Coover, D., Owen, S.V.: Development and Validity of the Computer Selfefficacy Scale. Educ. Psychol. Meas. 49(4), 893-899 (1989)

32. Brinkley, T., Scholar, M.: Women in Information Technology: Examining the Role of Attitudes, Social Norms, and Behavioral Control in Information Technology Career Choices. WSU McNair Journal 3, 24-40 (2005)

33. Seymour, L., Hart, M., Haralamous, P., Natha, T., Wend, C.: Inclination of Scholars to Major in Information Systems or Computer Science. In: Proceedings of SAICSIT, Stellenbosch, pp. 97-106 (2004)

34. Tekinarslan, E.: Computer Anxiety: a Cross-Cultural Comparative Study of Dutch and Turkish University Students. Comput. Hum. Behav. 24, 1572-1584 (2008) 